\title{
Influence of Abattoir Wastes on Groundwater Quality in Keffi, North Central Nigeria
}

\author{
J. B. Ahmed $\mathrm{II}^{1}$, A. Moumouni ${ }^{2}$, S. S. Musa ${ }^{3}$ \\ ${ }^{I}$ Department of Geology, Federal University Lokoja, Kogi State \\ ${ }^{2}$ Department of Geology, University Dan Dicko Dankoulo, Maradi, Niger \\ ${ }^{3}$ Dept. of Crop Tech. Federal College of Forestry Mechanization, Afaka, Kaduna
}

\begin{abstract}
Daily activities within our abattoirs are usually associated with some pollution problems especially when generated wastes are not properly disposed. The present study examines the groundwater quality around abattoirs in Keffi, Nasarawa State, Nigeria. Well-water samples from nine different locations were obtained. The study area was divided into three (3) zones viz; no abattoir area, central abattoir area and mini abattoir area respectively. The results from field and laboratory analysis showed that the samples from abattoir areas have higher concentrations of many of the parameters tested than those away from any abattoir. The abattoirs were seen to influence the concentrations of sodium, chloride, calcium, potassium, nitrate, sulphate and $\mathrm{pH}$. Result of the analysis was also compared with World Health Organization (WHO) and Nigeria Standard for Drinking Water Quality (NSDWQ) and revealed that most parameters are within the guideline values except magnesium, potassium, electrical conductivity and total dissolved solids in some samples while the microbial content suggests that the samples are somewhat polluted and not safe for consumption without treatment.
\end{abstract}

Keywords: Abattoir, Keffi, Nigeria, water quality, well water

\section{Introduction}

The most important challenges of today's water resources management throughout the world are considered to be water scarcity, environmental degradation, economic development and ineffective administration [1]. With worldwide awareness of pollution problems, various standards for drinking water have been developed based on toxicity of numerous substances which are commonly detected in drinking water. Some of these standards are developed by World Health Organization (WHO), United States Environmental Protection Agency (USEPA), European Union (EU), Federal Environmental Protection Agency (FEPA), and Nigeria Standard for Drinking Water Quality (NSDWQ) among others [2].

Activities undertaken within our abattoirs include slaughtering of cattle, sheep, goats, pigs, and other equine animals. The characteristics of slaughter house waste and effluent vary from day to day depending on the number, types of stock being processed and the method [3]. Waste generated by abattoirs include solid waste, made up of paunch content, bones, horns and feacal components, slurry of suspended solids, fat, blood and soluble materials [3][4]. These wastes from abattoir operations can also be separated into solid, liquid and fat. These wastes are highly organic. The solid waste includes condensed meat, undigested ingesta, bones, horns hairs and aborted fetuses. The liquid waste is usually composed of dissolved solids, blood and gut contents, urine and water, while fat waste consists of fat/oil, grease which are characterized with high organic levels [5]. Wells in vicinity of abattoirs which serves as source of water to the abattoir users was traced by [4] to be polluted by effluent from the abattoir and constitute health risk for the butchers and users of the wells. According to [6], abattoir effluents could considerably increase levels of nitrogen, phosphorous, and total solids in the receiving water body.

The provision of basic social amenities including portable water, is sole responsibility of government at various levels be it at Federal, State or Local level. But in most cases, provision of such amenities in Nigeria is characterized by low productivity, small coverage and inefficient service delivery and as a result people on private capacities explore other options such as wells and boreholes which in most cases, the qualities are not guaranteed and cases of health problems may result from drinking such waters. Hence, the present study aims at investigating groundwater quality from hand-dug wells around abattoirs in Keffi metropolis in order to understand the impact of abattoir daily activities on groundwater.

\section{Presentation and Geology of the Study Area}

Keffi town is located between latitudes N $08^{\circ} 46^{\prime}$ and N $08^{\circ} 53^{\prime}$ and longitudes $07^{0} 49^{\prime} \mathrm{E}$ and $07^{\circ} 55^{\prime} \mathrm{E}$. It is the Headquarters of Keffi Local Government Area, one of the thirteen Local Government Areas of Nasarawa State. The town is situated about 50 kilometers south of the Federal Capital Territory, Abuja. The town has experienced steady growth in population as a result of the creation of Nasarawa State University and influx of civil servants working in Abuja.

DOI: $10.9790 / 2402-1010013542 \quad$ www.iosrjournals.org $\quad 35 \mid$ Page


Water supply to Keffi town is largely from Mada Water Works where water from Mada River is treated and supplied to Keffi town and its environs. Quite recently, the supply has been epileptic causing residents to explore other options such as hand-dug wells and boreholes to supplement the public supply. Thus, the objective of this study is to investigate whether or not these abattoirs have impact on the water quality of the hand-dug wells.

Keffi town has two abattoirs; the central abattoir and a mini abattoir (Yan Awaki). Pipe-borne water does not adequately supply the abattoir areas, hence groundwater through wells and boreholes serve as the main source of water supply for the residents of the area. Two varieties of livestock are slaughtered in the central abattoir, which include an average of 15 cows and 30 goats daily while in the mini abattoir, only goats are slaughtered, an average of 50 daily. These figures however, soar during festive periods of Sallah and Christmas.

A lot of wastes are generated from the abattoir activities and these includes paunch content, faeces, horns, bones, fats and blood among others which in most cases are improperly disposed within the vicinity. Surface water may carry with it mobile parts of the wastes and infiltrates into the ground through cracks, voids and spaces between particles to groundwater and can contaminate the valuable resource. This is evident from the well waters around the central abattoir which after rainfall becomes turbid with strong offensive odour.

Geologically, the study area is characterized by near surface outcrops of underlying basement rocks and shallow overburden (fig. 1). Migmatites, schist and phyllites with intrusions of pegmatites, quartz and aplite veins are well exposed in the study area [7]. Migmatite rock covers the western portion of the study area occupying about $45 \%$ of total area. The most conspicuous exposure is behind the Keffi central abattoir where it forms an inselberg popularly called 'Maloney Hill rising from the plains to a maximum elevation of 406 meters above sea-level and trending exactly north-south. Rocks of schistose lithology occupy about $48 \%$ of the study area and overlie most of the eastern half of the area outcropping mainly along stream channels. The schists are highly weathered metamorphic rocks with their minerals aligned in one direction in response to deformation stress. Phyllite forms an isolated outcrop exposed under the Mallam Nuhu bridge along the Akwanga - Abuja express way up to parts of GRA occupying about $7 \%$ of the total study area. Outcrops are very hard, dark in colour, fine to medium coarse grained, with biotite mica as the dominant mineral. The outcrops are broken into boulders by river action and trends in the north-south direction that gradually grades into schist. Pegmatite, quartz and aplite veins are the main intrusive structures cutting through migmatite and schist rocks.

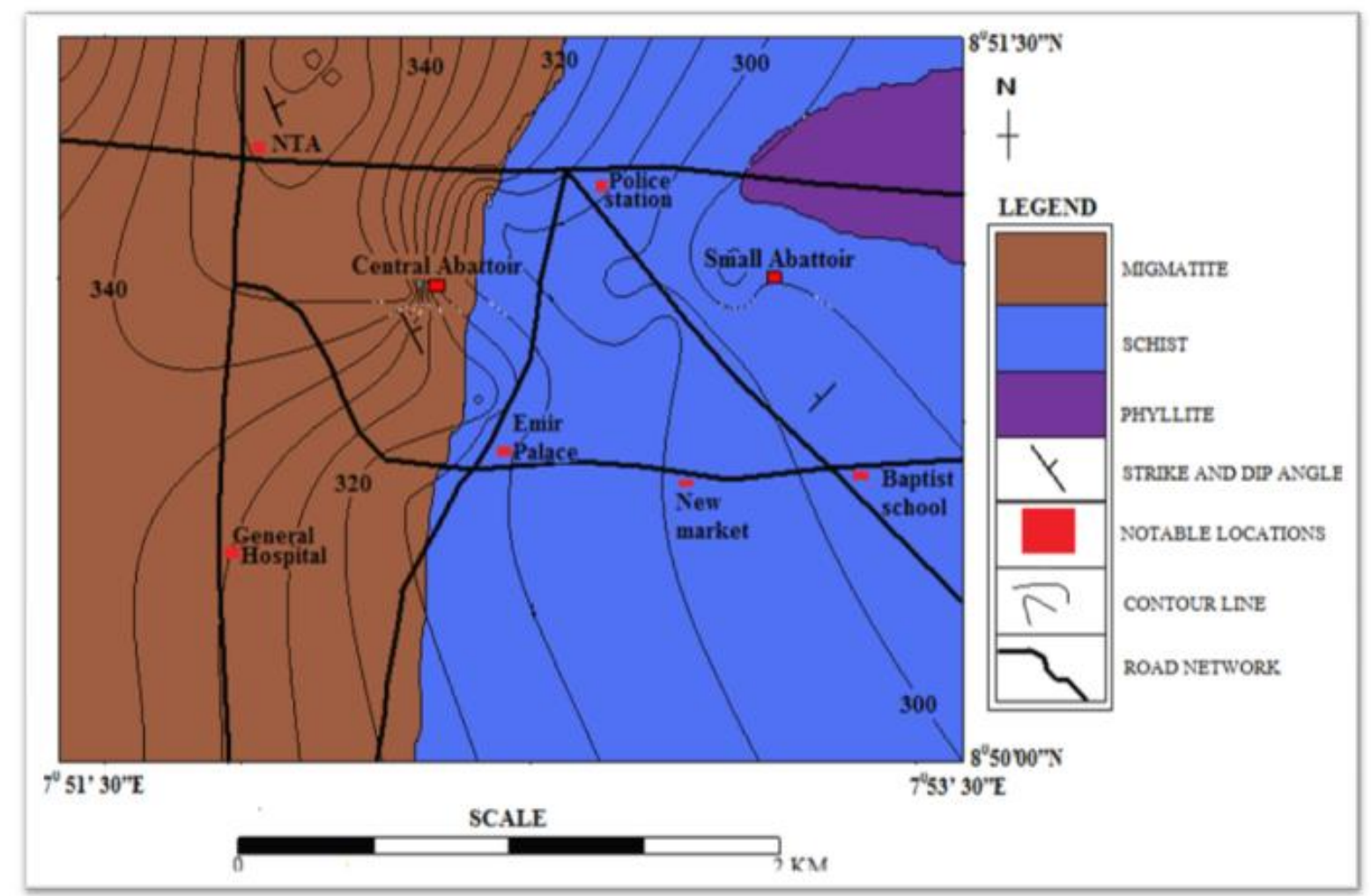

Figure 1: Geological map of the study area 


\section{Material and Method}

\subsection{Sample Collection and Preservation}

Groundwater samples were obtained from nine (9) hand-dug wells spread across the study area (fig. 2). The entire study area was divided into three (3) zones namely; Zone A (Area away from any abattoir), Zone B (Central Abattoir area) and Zone C (Mini Abattoir area). About 80\% of the wells are well covered and highly patronized to supplement the epileptic pipe-borne water supply. The sampling was done during the peak of wet season (August) because physical manifestation of the water contamination is observed during this period. All the samples were collected in 1.5 liter plastic bottles which were thoroughly rinsed with the waters to be sampled, adequately labeled with the coordinate location, temperature and $\mathrm{pH}$ of the sample then wrapped in black polythene bags, stored in refrigerator and taken to laboratory in ice packed cooler the following day for analysis.

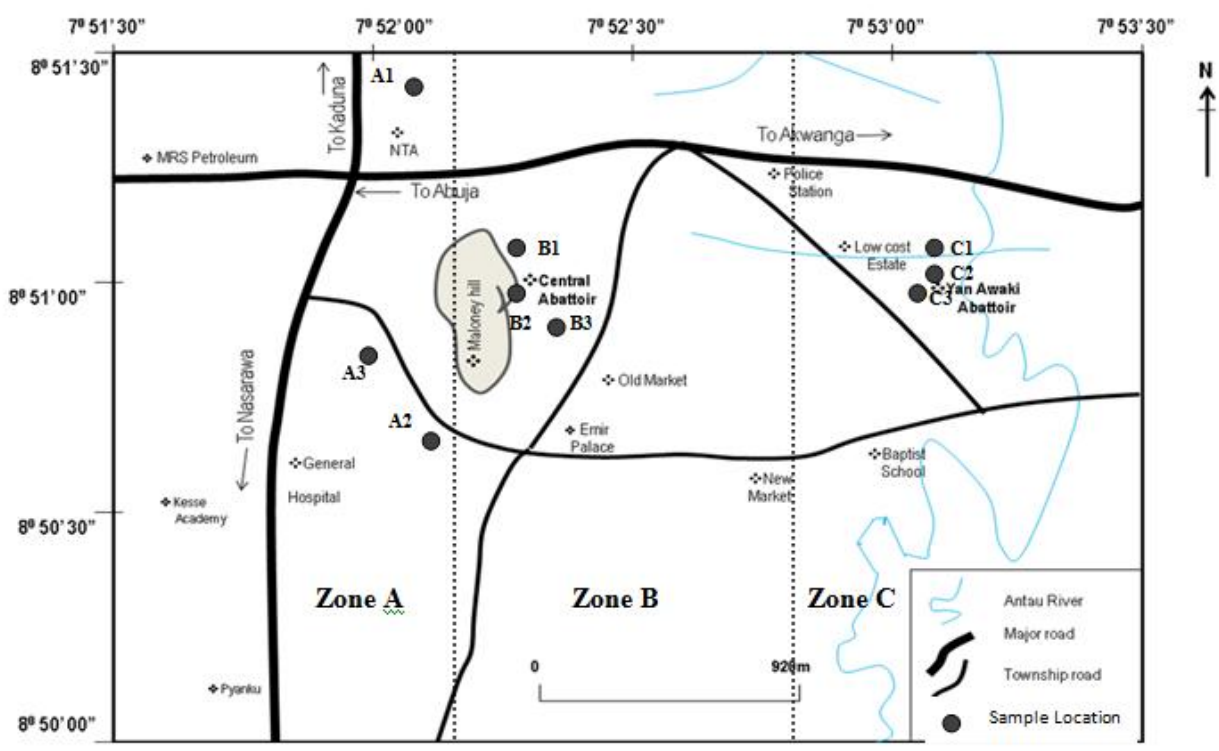

Figure 2: Sample location map of the study area

\subsection{Sample Analysis}

The physical parameters of the water were tested on the field. These include; odour and taste using the nose and tongue respectively, $\mathrm{pH}$, electrical conductivity, Total Dissolved Solids (TDS) and temperature using a portable Martini instrument Mi 806. Chemical and microbiological tests were conducted in the Regional Water Quality Laboratory of the Federal Ministry of Water Resources Minna, Niger State. The water samples were analyzed following procedures as recommended by [8][9][10]. The parameters investigated include; Calcium $\left(\mathrm{Ca}^{2+}\right)$ Magnesium $\left(\mathrm{Mg}^{2+}\right.$, Potassium $\left(\mathrm{K}^{+}\right)$, Sodium $\left(\mathrm{Na}^{+}\right)$, Nitrate $\left(\mathrm{NO}_{3}\right)$, Bicarbonate $\left(\mathrm{HCO}_{3}^{-}\right)$, Chloride $\left(\mathrm{Cl}^{-}\right)$, Sulphate $\left(\mathrm{SO}_{4}{ }^{2-}\right)$, Iron $\left(\mathrm{Fe}^{2+}\right)$, Total Coliform count and Escherichia coli.

\section{Results and Discussion}

Tables 1-8 presents the chemical concentrations and physical analysis results of all nine (9) well water samples in the study area.

Table 1: Chemical concentration $(\mathrm{mg} / \mathrm{L})$ of well water samples from Zone A

\begin{tabular}{|l|l|l|l|l|l|l|}
\hline Parameters & $\mathbf{A 1}$ & $\mathbf{A 2}$ & $\mathbf{A 3}$ & $\mathbf{X}$ & $\mathbf{S D}$ & $\mathbf{C V \%}$ \\
\hline $\mathbf{C a}_{2}{ }^{+}$ & 5.6 & 8.8 & 10.4 & 8.27 & 2.44 & 29.6 \\
\hline $\mathbf{M g}_{2}{ }^{+}$ & 16.1 & 58.1 & 33.18 & 35.79 & 21.12 & 59.0 \\
\hline $\mathbf{N a}^{+}$ & 22.0 & 56.0 & 73.2 & 28.44 & 24.97 & 87.8 \\
\hline $\mathbf{K}^{+}$ & 2.68 & 15.4 & 5.36 & 7.81 & 6.71 & 85.8 \\
\hline $\mathbf{C l}^{-}$ & 8.15 & 195.7 & 16.3 & 73.38 & 106.01 & 144 \\
\hline $\mathbf{N O}_{3}{ }^{-}$ & 2.12 & 1.59 & 1.60 & 1.77 & 0.30 & 17.1 \\
\hline $\mathbf{S O}_{4}{ }^{-}$ & 1.4 & 0.9 & 3.9 & 2.07 & 1.61 & 77.8 \\
\hline $\mathbf{H C O}_{3}{ }^{-}$ & 7.0 & 21.0 & 6.0 & 11.33 & 8.39 & 74.0 \\
\hline $\mathbf{F e}^{2+}$ & 0.012 & 0.023 & 0.021 & 0.019 & 0.0059 & 31.3 \\
\hline
\end{tabular}

$\mathrm{X}=$ Grand mean; SD = Standard Deviation, CV\% = Coefficient of variation percent. 
Table 1 above presents the result of chemical concentration in the wells located in Zone A. Sodium is the most concentrated chemical element in the water samples ranging from $22.0 \mathrm{mg} / \mathrm{L}$ in sample A1 to $73.3 \mathrm{mg} / \mathrm{L}$ in sample A3. This is followed by magnesium which ranged from $16.1 \mathrm{mg} / \mathrm{L}$ in sample A1 to $58.1 \mathrm{mg} / \mathrm{L}$ in sample A2. Chloride recorded a high value of $195 \mathrm{mg} / \mathrm{L}$ in sample A2. Iron is the lowest concentrated chemical element ranging from $0.012 \mathrm{mg} / \mathrm{L}$ to $0.023 \mathrm{mg} / \mathrm{L}$. The most highly varied chemical element is chloride $(144 \%)$ followed by sodium (85.8\%) while the least variation is recorded on nitrate (17.1\%). In table 2 below, the result of chemical concentration in wells located in Zone B is presented. Chloride has the highest concentration ranging from $97.8 \mathrm{mg} / \mathrm{L}$ in sample B1 to $236.5 \mathrm{mg} / \mathrm{L}$ in sample B2, followed by Magnesium which ranged from $77.6 \mathrm{mg} / \mathrm{L}$ in sample B1 to $118.1 \mathrm{mg} / \mathrm{L}$ in sample B3. Iron has the least concentration ranging from $0.00 \mathrm{mg} / \mathrm{L} \mathrm{in}$ sample B2 to $0.032 \mathrm{mg} / \mathrm{L}$ in sample B3. The most highly varied chemical element is nitrate $(132.3 \%)$ while the least is sulphate $(17.9 \%)$.

Table 2: Chemical concentration $(\mathrm{mg} / \mathrm{L})$ of well water samples from Zone B

\begin{tabular}{l|lllllr}
\hline Parameters & B1 & B2 & B3 & X & SD & CV\% \\
\hline $\mathbf{C a}_{2}{ }^{+}$ & 7.2 & 5.6 & 10.4 & 7.73 & 2.44 & 31.6 \\
$\mathbf{M g}_{2}{ }^{+}$ & 77.6 & 108.3 & 118.1 & 101.30 & 21.13 & 20.9 \\
$\mathbf{N a}^{+}$ & 46.0 & 66.0 & 66.5 & 59.50 & 11.69 & 19.6 \\
$\mathbf{K}^{+}$ & 29.5 & 5.36 & 26.8 & 20.55 & 13.23 & 64.4 \\
$\mathbf{C l}^{-}$ & 97.8 & 236.5 & 171.2 & 168.50 & 69.39 & 41.1 \\
$\mathbf{N O}^{-}$ & 4.25 & 42.90 & 3.76 & 16.97 & 22.46 & 132.3 \\
$\mathbf{S O}_{4}{ }^{2-}$ & 5.2 & 6.0 & 7.4 & 6.20 & 1.11 & 17.9 \\
$\mathbf{H C O}_{3}^{-}$ & 13.5 & 5.0 & 12.5 & 10.33 & 4.65 & 44.9 \\
$\mathbf{F e}^{2+}$ & 0.01 & 0.00 & 0.032 & 0.014 & 0.016 & 116.9 \\
\hline
\end{tabular}

Table 3 below shows result of chemical concentration in wells located in Zone C. The highest concentration is recorded in chloride which ranges from $35.5 \mathrm{mg} / \mathrm{L}$ in sample $\mathrm{C} 1$ and $106.4 \mathrm{mg} / \mathrm{L}$ in sample C2, followed by sodium which ranged from $40.5 \mathrm{mg} / \mathrm{L}$ in sample $\mathrm{C} 1$ to $72.9 \mathrm{mg} / \mathrm{L}$ in sample $\mathrm{C} 2$. The least concentrated chemical element is iron which ranged from $0.11 \mathrm{mg} / \mathrm{L}$ in sample $\mathrm{C} 3$ to $0.30 \mathrm{mg} / \mathrm{L}$ in sample $\mathrm{C} 2$. The highest variation is recorded on nitrate $(107.4 \%)$ while the least is bicarbonate $(10.2 \%)$.

Table 3: Chemical concentration $(\mathrm{mg} / \mathrm{L})$ of well water samples from Zone $\mathrm{C}$

\begin{tabular}{|c|c|c|c|c|c|c|}
\hline Parameters & $\mathrm{C} 1$ & $\mathrm{C} 2$ & $\mathrm{C} 3$ & $\overline{\mathbf{X}}$ & SD & CV\% \\
\hline $\mathrm{Ca}_{2}{ }^{+}$ & 28.1 & 61.7 & 60.1 & 49.97 & 18.95 & 37.9 \\
\hline $\mathrm{Mg}_{2}{ }^{+}$ & 14.1 & 28.1 & 14.3 & 18.83 & 8.03 & 42.6 \\
\hline $\mathrm{Na}^{+}$ & 40.5 & 72.9 & 56.7 & 56.70 & 16.20 & 28.6 \\
\hline $\mathbf{K}^{+}$ & 16.0 & 35.2 & 42.6 & 31.27 & 11.20 & 43.9 \\
\hline $\mathrm{Cl}^{-}$ & 35.5 & 106.4 & 97.5 & 79.80 & 38.62 & 48.4 \\
\hline $\mathrm{NO}_{3}^{-}$ & 10.3 & 27.9 & 0.53 & 12.91 & 13.87 & 107.4 \\
\hline $\mathrm{SO}_{4}^{2-}$ & 27.0 & 43.1 & 12.0 & 27.37 & 15.55 & 56.8 \\
\hline $\mathrm{HCO}_{3}^{-}$ & 35.5 & 42.9 & 37.0 & 38.47 & 3.91 & 10.2 \\
\hline $\mathrm{Fe}^{2+}$ & 0.29 & 0.30 & 0.11 & 0.23 & 0.11 & 45.8 \\
\hline
\end{tabular}

Table 4: Summary of chemical concentration $(\mathrm{mg} / \mathrm{L})$ of the well water samples from Zone A, B and C

\begin{tabular}{l|lcccl}
\hline Parameters & Zone A & Zone B & Zone C & WHO 2012 & NIS 554:2007 \\
\hline $\mathbf{C a}^{+}$ & 8.27 & 7.73 & 49.97 & 75 & na \\
$\mathbf{M g}_{2}{ }^{+}$ & 35.79 & 101.30 & 18.83 & 30 & 0.2 \\
$\mathbf{N a}^{+}$ & 28.44 & 59.50 & 56.70 & 200 & 200 \\
$\mathbf{K}^{+}$ & 7.81 & 20.55 & 31.27 & 12 & na \\
$\mathbf{C l}$ & 73.38 & 168.50 & 79.80 & 200 & 250 \\
$\mathbf{N O}_{3}{ }^{-}$ & 1.77 & 16.97 & 12.91 & 25 & 50 \\
$\mathbf{S O}_{4}{ }^{2-}$ & 2.07 & 6.20 & 27.37 & 200 & 100 \\
$\mathbf{H C O}_{3}{ }^{-}$ & 11.33 & 10.33 & 38.47 & 250 & na \\
$\mathbf{F e}^{2+}$ & 0.019 & 0.014 & 0.23 & 0.1 & 0.3 \\
\hline
\end{tabular}

na $=$ not available 
A summary of the chemical concentration of the well water samples is presented in table 4 above. Chloride has the highest concentration in all the water samples ranging from $73.38 \mathrm{mg} / \mathrm{L}$ in Zone A to $168.50 \mathrm{mg} / \mathrm{L}$ in Zone B. Chloride is the most stable components in water [11] and can usually be found in the ground as rock salts or halite. High chloride loads may be related to a variety of factors, including increases in road area and consequent deicing, increases in wastewater and septic-system discharges, sewage and animal waste, and leachate from landfills and salt storage areas [12]. Chloride plays the vital role of lengthening the life-expectancy of humans through disinfection and deactivation of most pathogens in water. Although not usually harmful to people, the sodium part of table salt has been linked to heart and kidney disease. Long term drinking of chlorinated water is also associated with increase in developing bladder and rectal cancers [12]. The chloride content of the water samples fall within the WHO recommended range of $200 \mathrm{mg} / \mathrm{L}$ and could be said to be desirable for drinking without adverse effects. Water samples from Zone B (central abattoir area) recorded high chloride value with reasons not far from deposition of animal wastes around the area.

Magnesium and Sodium are next in terms of concentration and ranged from $18.83 \mathrm{mg} / \mathrm{L}$ in Zone $\mathrm{C}$ to $101.30 \mathrm{mg} / \mathrm{L}$ in Zone B and $28.44 \mathrm{mg} / \mathrm{L}$ in Zone A to $59.50 \mathrm{mg} / \mathrm{L}$ in Zone B respectively. Magnesium is a dietary mineral for humans, one of the micro element that is responsible for membrane function, nerve stimulant transmission, muscle contradiction, protein construction and DNA replication. It is also an ingredient of many enzymes. Sodium on the other hand is a dietary mineral for animals. In humans, it is partially responsible for nerve functions. It regulates extra cellular fluids, acid-base balance and membrane potential, partially together with potassium. Sodium overdose may cause increased blood pressure, arteriosclerosis, oedema, hyperosmolarity, and confusion while shortages may lead to dehydration, convulsion, muscle paralysis, decreased growth and general numbness. Zone B where the central abattoir is located has the highest concentration of magnesium $(101.30 \mathrm{mg} / \mathrm{L})$ followed by Zone A $(35.79 \mathrm{mg} / \mathrm{L})$ which is away from the abattoir. Going by the WHO guideline, water from Zones A and B are considered not safe for drinking (hard water). The Nigerian Standard for Drinking Water Quality (NIS 554:2007) recommended magnesium concentration of $0.2 \mathrm{mg} / \mathrm{L}$ in drinking water, which as a result rendered water from all the zones not safe for consumption. Sodium concentrations are higher around the abattoir areas signifying abattoir influence on its concentration. Sodium is sourced from rocks and soils washed by moving water ending up in oceans, rivers and lakes but according to [13] sodium can also be sourced from deposited wastes. However, sodium concentrations are within the WHO and Nigerian standard guideline values of $200 \mathrm{mg} / \mathrm{L}$ respectively.

Bicarbonate concentration falls under the WHO recommended guideline of $250 \mathrm{mg} / \mathrm{L}$. The highest concentration is found in Zone C $(38.47 \mathrm{mg} / \mathrm{L})$ where the mini abattoir is located, but are generally considered safe for consumption. Bicarbonate is fundamental for our bodies and is found in all biological fluids.

Calcium is a dietary requirement for all organisms apart from some insects and bacteria. It is a building stone of skeletons of most marine organisms, and eye lenses. The surest source of calcium is in drinking water as the body is most easily able to absorb calcium carried along in the mineral drinking water. Together with magnesium, calcium is an important determinant of water hardness and functions as a $\mathrm{pH}$ stabilizer because of its buffering qualities. It also gives water a better taste [13]. Lack of calcium is one of the main causes of osteoporosis, a disease in which the bones become extremely porous, and subjectable to fracture and heal slowly [14]. Calcium occurs in water naturally as it may be dissolved from rocks such as limestone, marble, calcite, dolomite, gypsum, fluorite and apatite. Highest concentrations of calcium is found in Zone C $(49.97 \mathrm{mg} / \mathrm{L})$ around the mini abattoir area but are generally under the WHO guideline of $75 \mathrm{mg} / \mathrm{L}$.

Potassium concentrations are higher around the abattoir areas where $20.55 \mathrm{mg} / \mathrm{L}$ and $31.27 \mathrm{mg} / \mathrm{L}$ are recorded for Zone $\mathrm{B}$ and $\mathrm{C}$ respectively. The recorded values around the abattoir areas are above the WHO guidelines for drinking water $(12 \mathrm{mg} / \mathrm{L})$ indicating influence of the abattoirs as regards its concentration and are considered not safe for consumption. Potassium is mainly sourced from fertilizers and plants [13]. Being an essential element, it is present in the tissues of all plants and animals. High concentration of potassium may be particularly harmful example, high doses of potassium chloride interferes with nerve impulses, which interrupts with virtually all bodily functions and mainly affects heart functioning.

Nitrate and sulphate concentrations are all under the WHO $(25 \mathrm{mg} / \mathrm{L})$ and Nigerian Standard $(50 \mathrm{mg} / \mathrm{L})$ guideline values and can be considered safe for consumption. However, the concentrations of these elements are higher around the abattoirs $(16.97 \mathrm{mg} / \mathrm{L}$ and $6.20 \mathrm{mg} / \mathrm{L}$ in Zone $\mathrm{B}, 12.91 \mathrm{mg} / \mathrm{L}$ and $27.37 \mathrm{mg} / \mathrm{L}$ in Zone C respectively) while very low concentrations are recorded away from the abattoirs $(1.77 \mathrm{mg} / \mathrm{L}$ and $2.07 \mathrm{mg} / \mathrm{L}$ respectively for nitrate and sulphate concentrations in Zone A) thus signifying the influence of abattoirs as regards their concentrations. Although nitrate occurs naturally, in most cases higher levels are thought to result from human activities such as fertilizers and manures, animal feedlots and wastes, municipal wastewater and sludge, septic systems and N-fixation from atmosphere by legumes, bacteria and lightening [15]. High nitrate levels in water can cause blue baby syndrome, a condition found especially in infants under six months which reduce oxygen supply to vital tissues such as the brain [14]. Sulphate can be found in almost all natural water. The origin of most sulphate compounds is the oxidation of sulphite ores, the presence of shales or industrial 
wastes. It can also be formed from decomposing underground deposits of organic matter such as decaying and animal material [16].

Table 5: Physical analysis of water samples from Zone A

\begin{tabular}{l|lccccc}
\hline Parameters & \multicolumn{1}{|c}{$\mathbf{A 1}$} & $\mathbf{A 2}$ & $\mathbf{A 3}$ & $\overline{\mathbf{X}}$ & SD & CV\% \\
\hline Taste & tasteless & bitter & bitter & - & - & - \\
Odour & odourless & odourless & odourless & - & - & \\
pH & 6.33 & 6.04 & 6.88 & 6.42 & 0.43 & 6.5 \\
Conductivity & 219 & 980 & 425 & 541.3 & 393.61 & 72.7 \\
Temp. & 27.5 & 27.9 & 27.4 & 27.6 & 0.265 & 0.96 \\
TDS & 146.1 & 656.6 & 1238.8 & 680.5 & 546.74 & 80.3 \\
\hline
\end{tabular}

Table 5 above presents the physical analysis result of water samples from Zone A. Samples ranged from being tasteless (A1) to having bitter taste (A2 and A3) while all the samples are odourless. The pH values range from 6.04 (A2) and 6.88 (A3) while electrical conductivity values ranged from $219 \mu \mathrm{S} / \mathrm{cm}$ (A1) and $980 \mu \mathrm{S} / \mathrm{cm}(\mathrm{A} 2)$. The water temperatures ranged from $27.4^{\circ} \mathrm{C}(\mathrm{A} 3)$ and $27.9^{\circ} \mathrm{C}(\mathrm{A} 2)$ while total dissolved solids ranged from $146.1 \mathrm{mg} / \mathrm{l}(\mathrm{A} 1)$ and $1238.8 \mathrm{mg} / \mathrm{l}$ (A3). The most varied parameter is total dissolved solids $(80.3 \%)$ while the least is temperature $(0.96 \%)$.

Table 6: Physical analysis of water samples from Zone B

\begin{tabular}{l|lccccc}
\hline Parameters & \multicolumn{1}{|c}{ B1 } & B2 & B3 & $\overline{\mathbf{X}}$ & SD & CV\% \\
\hline Taste & n.a & bitter & bitter & - & - & \\
Odour & stinking & odourless & odourless & - & - & \\
pH & 7.97 & 6.40 & 7.05 & 7.14 & 0.789 & 11.0 \\
Conductivity & 808 & 1303 & 1510 & 1207 & 360.71 & 29.9 \\
Temp. & 23.1 & 27.5 & 27.8 & 26.1 & 2.63 & 10.07 \\
TDS & 541.4 & 873 & 1011.7 & 808.7 & 241.65 & 29.9 \\
\hline
\end{tabular}

$\overline{\mathrm{X}}=\mathrm{Mean} ; \mathrm{SD}=$ Standard Deviation, $\mathrm{CV} \%=$ Coefficient of variation percent, $\mathrm{n} . \mathrm{a}=$ not available

In table 6 above, physical analysis result of water samples from Zone B is presented. The samples have bitter taste and ranged in odour from stinking smell to odourless. The $\mathrm{pH}$ and conductivity values are relatively high ranging from 6.40 (B2) to 7.97 (B1) in $\mathrm{pH}$ and $808 \mu \mathrm{S} / \mathrm{cm}$ (B1) and $1510 \mu \mathrm{S} / \mathrm{cm}$ (B3) in conductivity. Temperature values ranged from $23.1^{\circ} \mathrm{C}$ (B1) to $27.8^{\circ} \mathrm{C}$ (B3) while total dissolved solids ranged from $541.4 \mathrm{mg} / \mathrm{L}$ (B1) and $1011.7 \mathrm{mg} / \mathrm{L}$ (B3). The highest variability is on conductivity and total dissolved solid $(29.9 \%)$ while the least is on temperature $(10.07 \%)$.

Table 7: Physical analysis of water samples from Zone C

\begin{tabular}{l|lccccc}
\hline Parameters & \multicolumn{1}{c}{$\mathbf{C 1}$} & $\mathbf{C 2}$ & $\mathbf{C 3}$ & $\overline{\mathbf{X}}$ & SD & CV\% \\
\hline Taste & tasteless & bitter & tasteless & - & - & \\
Odour & odourless & odourless & odourless & - & - & \\
pH & 8.08 & 8.93 & 8.66 & 8.56 & 0.43 & 5.08 \\
Conductivity & 283 & 818 & 610 & 570.33 & 269.69 & 47.3 \\
Temp. & 27.5 & 27.2 & 27.2 & 27.30 & 0.17 & 0.63 \\
TDS & 189.6 & 548.1 & 408.7 & 382.13 & 180.72 & 47.3 \\
\hline
\end{tabular}

Water samples from Zone $\mathrm{C}$ as presented on table 7 above shows that the samples are more tasteless (C1 and C3) with only sample C2 having bitter taste. All samples are odourless with high pH values that ranged from $8.08(\mathrm{C} 1)$ to $8.93(\mathrm{C} 2)$. Conductivity values on the other hand ranged from $283 \mu \mathrm{S} / \mathrm{cm}(\mathrm{C} 1)$ to $818 \mu \mathrm{S} / \mathrm{cm}$ (C2) while temperature values ranged from $27.2^{\circ} \mathrm{C}(\mathrm{C} 2$ and $\mathrm{C} 3)$ to $27.5^{\circ} \mathrm{C}(\mathrm{C} 1)$ and total dissolved solids ranged from $189.6 \mathrm{mg} / \mathrm{L}(\mathrm{C} 1)$ to $548.1 \mathrm{mg} / \mathrm{L}(\mathrm{C} 2)$. The highest varied parameters are conductivity and total dissolved solid $(47.3 \%)$ while the least is temperature $(0.63 \%)$ 
Table 8: Summary of Physical analysis of water samples from Zone A, B and C

\begin{tabular}{l|lcccc}
\hline Parameters & Zone A & Zone B & Zone C & WHO 2011 & NIS 554:2007 \\
\hline Taste & tasteless/bitter & bitter & tasteless/bitter & tasteless & tasteless \\
Odour & odourless & stinking/odourless & odourless & odourless & odourless \\
pH & 6.42 & 7.14 & 8.56 & $6.5-8.5$ & $6.5-8.5$ \\
Conductivity & 541.3 & 1207 & 570.33 & 1000 & 1000 \\
Temp. & 27.6 & 26.1 & 27.3 & na & na \\
TDS & 680.5 & 808.7 & 382.13 & 600 & 600 \\
\hline
\end{tabular}

Table 8 above shows the summary of physical parameters of well water samples from the study area. Water samples from Zone A are mainly tasteless but bitter taste exit in a few while all samples from Zone B are tasteless, bitter taste is observed in some parts of Zone C. However, drinking water according to both WHO and Nigerian standards is supposed to be tasteless. Abattoir presence is not observed to affect the water taste here. Samples Zone A and C are free from any odour but in Zone B, stinking smell of organic matter was perceived and this is a primary effect of the abattoir presence. Again, drinking water is presumed to be odourless.

$\mathrm{pH}$, the degree of acidity or basicity of an aqueous solution should range between $6.5-8.5$ for safe drinking water as opined by the both standards. Water sample from Zone A (6.42) is more acidic and falls a little below the standard while samples from other zones (B and C) are more basic (7.14 and 8.56) with sample from Zone $\mathrm{C}$ a little above the standard. $\mathrm{pH}$ concentration is higher around the abattoir area. Electrical conductivity of water measures the ability of water to conduct electric current. It is an indicator of how salt-free, ion-free or impurity free a water sample is and its level in water is not to exceed $1000 \mu \mathrm{S} / \mathrm{cm}$. The conductivity is higher around the abattoirs with that of Zone B $(1207 \mu \mathrm{S} / \mathrm{cm})$ exceeding the WHO and Nigerian standard guideline value. This means that water samples around the abattoirs contains more salt, ion or impurity than areas away from it.

Total dissolved solid (TDS) comprises inorganic salts (principally calcium, magnesium, potassium, sodium, bicarbonates, chlorides and sulfates) and small amounts of organic matter that are dissolved in water. TDS in drinking-water originates from natural sources, sewage, urban runoff and industrial wastewater. The palatability of water with a TDS level of less than about $600 \mathrm{mg} / \mathrm{l}$ is generally considered to be good for drinking [14] as the water becomes significantly and increasingly unpalatable at greater levels. High TDS value that exceed the guideline value is found in Zone B $(808.7 \mathrm{mg} / \mathrm{L})$ and Zone A $(680.5 \mathrm{mg} / \mathrm{L})$ therefore considered not very safe for consumption. However, influence of abattoir as regards TDS concentration is not clear as Zone $\mathrm{C}$ has a low concentration of it.

Table 9: Summary of microbial concentration (cfu/100ml) of the well water samples from Zone A, B and C

\begin{tabular}{l|lcccc}
\hline Parameters & Zone A & Zone B & Zone C & WHO 2011 & NIS 554:2007 \\
\hline Coliform count & 32 & 27 & 39 & 10 & 10 \\
E. coli & 7 & 1 & 0 & 0 & 0 \\
\hline
\end{tabular}

Table 9 above presents the summary of microbial concentration in the well waters. Total coliform count gives a general indication of the sanitary condition of a water supply while Escherichia coliform (E. coli) indicates faecal pollution and presence of disease causing pathogens [1]. Amazingly, water samples from Zone A recorded higher coliform count as well as faecal concentration than Zones B and C where the abattoirs resides. Faecal concentration in Zone A can be attributed to septic tank leakages and deposition of other human wastes into the wells because the area is mainly residential.

\section{Conclusion}

The study highlighted the dangers posed by improper dumping of abattoir waste on groundwater of the study area. Activities ongoing in the abattoir include slaughtering, butchering, roasting animal skin, keeping livestock and their feedlots which generate wastes that include flesh, skin, bones, blood etc. that are dumped within the vicinity of the abattoirs and can become infiltrated into groundwater. Results from physico-chemical analysis showed that most of the parameters analyzed for the water samples are within the World Health Organization and Nigerian standard limit for drinking water except magnesium, potassium, electrical conductivity and total dissolved solids in some samples. The abattoir influence on the concentration of some parameters including sodium, chloride, calcium, potassium, nitrate, sulphate, $\mathrm{pH}$ and electrical conductivity was 
well established. Reasons for the higher concentrations are not unconnected to the method of disposal of generated wastes which ranged from dumping/burning of animal bones, tusk, blood, cattle faeces, manure, feedlots, decomposing organic matter and decaying animal material. Microbial analysis of the samples suggests that all the water samples are not safe for consumption and need to be properly treated to prevent outbreak of diseases.

It will be important for relevant authorities to put in place effluent treatment facilities to treat wastes from these abattoirs and to provide safe disposal lands to curb further environmental health risks. Furthermore, water from these wells need to be treated either by boiling or chlorination to guarantee safeness.

\section{Acknowledgment}

The assistance rendered by Mr. Felix Ogundipe and Mr. Jamil Habu of Water Quality Laboratory of Federal Ministry of Water Resources, Minna Regional office is highly acknowledged.

\section{References}

[1]. M. M. Ndamitso, S. Idris, M. B. Likita, O. T. Jimoh, A. I. Ajai, and A. A. Bala, Physico-chemical and Escherichia coli assessment of selected sachet water produced in some areas of Minna, Niger State, Nigeria, International Journal of Water Resources and Environmental Engineering 5(3), 2013, 134 - 140.

[2]. M.O. Aremu, D.U. Sangari, B.Z. Musa, and M.S. Chaanda, Assessment of groundwater and stream quality for trace metals and physico-chemical contaminations in Toto Local Government Area of Nasarawa State, Nigeria, International Journal of Chemical Sciences. 1(1), 2008, 8-16. Nasarawa State University, Keffi, Nigeria.

[3]. J.Y. Magaji and C.D. Chup, The effects of abattoir waste on water quality in Gwagwalada-Abuja, Nigeria, Ethiopian Journal of Environmental Studies and Management, 5(4), 2012, 542-549.

[4]. A.O. Oyinlola and G.O. Jegede, Geophysical survey, geochemical and microbiological investigation of ground and well water in AdoEkiti, North-east, Southwestern Nigeria, Global Journal of Geological Sciences, 1(2), 2004, 235-238.

[5]. W.D. Nafarnda, A. Yayi and H.I. Kubkomawa, Impact of abattoir waste on aquatic life: A case study of Yola abattoir, Global Journal Pure \& Applied Science, 12, 2006, 31-33.

[6]. G.S. Mittal, Characterization of the effluent wastewater from abattoirs for land application, Journal Food Review International, 20, 2004, 229-256.

[7]. J.B. Ahmed II, I.A. Okunlola, I.N. Abdullahi, L.L. Kolawole, Assessment of effects of abattoir activities on groundwater quality in part of Keffi, North Central Nigeria, Water Resources, 23, 2013, 72-91.

[8]. ASTM Annual Book of Standards, 11(02), 1999, Philadelphia, PA, American Society for Testing and Materials.

[9]. APHA, Standard Methods for the Examination of Water and Wastewater ( $21^{\text {st }}$ Ed). Washington, DC. American Public Health Association, American Water Works Association and Water Environment Federation 1999.

[10]. EPA, Water Quality Criteria Fact Sheet. United States Environmental Protection Agency, (Washington DC: 2006).

[11]. A.C. Oludare, O.J. Adedepo and O. Balogun, Environmental safety, protection and policy for sustainable development, Environmental Review, 4(1), 2002, 515-527.

[12]. J.R. Mullaney, D.L. Lorenz and A.D. Arntson, Chloride in groundwater and surface water in areas underlain by the glacial aquifer system, Northern United States: U.S. Geological Survey Scientific Investigations Report, 2009, 2009-5086.

[13]. A.S. Hassan, Water quality for well drilling course under youth empowerment programme, Continuing Education Division, National Water Resources Institute, Kaduna, 2009, Unpublished.

[14]. WHO, Guidelines for drinking water quality $\left(4^{\text {th }}\right.$ Ed), 2011, World Health Organisation, Geneva.

[15]. S.E. Obrike, G.K. Anudu, S. Iyakwari, K. Nghargbu and C.C. Osadebe, Nitrate concentration and groundwater venerability in typical shallow basement aquifers around Keffi Area, North-Central Nigeria. International Journal of Chemical Sciences, 4(1), 2011, 120-125. Nasarawa State University, Keffi, Nigeria.

[16]. O. Brian, Sulfate, hydrogen sulfide, sulfate reducing bacteria - How to identify and manage. Retrieved from B.F. Environmental Consultants Incorporation website: http://www.water-research.net/sulfate.html 2010.

[17]. C.N. Akujieze, S.J.L. Coker, and G.E. Oteze, Groundwater in Nigeria - a millennium experience - distribution, practice, problems and solutions. Hydrogeology Journal, 11, 2003, 259-274.

[18]. M.S. Chaanda, A. Moumouni, N.G. Goki, M.O. Aremu and N.L. Binbol, Geochemical analysis of water quality in the Tilden Fulani Area of Bauchi State, Nigeria, International Journal of Chemical Sciences. 1(1), 2008, 163-167 Nasarawa State University, Keffi, Nigeria.

[19]. A. Moumouni, G. Ibrahim, M.S. Chaanda and P.C. Madu, Groundwater quality in Keffi Town and its Environs: A Preliminary Study. Indian Journal of Multidisciplinary Research, 4(1), 2008.

[20]. DailyTrust, Four Nasarawa varsity protesting students shot dead. Media Trust Limited, (26 February, 2013).

[21]. NSDWQ (Nigerian Standard for Drinking Water Quality), 2007. Draft version 2. 22. Federal Ministry of Health, Abuja. 